\title{
Comparative analysis of five DNA isolation protocols and three drying methods for leaves samples of Nectandra megapotamica (Spreng.) Mez
}

\author{
Análise comparativa de cinco protocolos de isolamento de DNA \\ e três métodos de secagem de amostras foliares de Nectandra \\ megapotamica (Spreng.) Mez
}

\author{
Leonardo Severo da Costa ${ }^{1}$; Lia Rejane Silveira Reiniger ${ }^{2 *}$; \\ Valdir Marcos Stefenon ${ }^{3}$; Berta Maria Heinzmann ${ }^{4}$; Adriel dos Santos Oliveira ${ }^{5}$
}

\begin{abstract}
The aim of the study was to establish a DNA isolation protocol Nectandra megapotamica (Spreng.) Mez., able to obtain samples of high yield and quality for use in genomic analysis. A commercial kit and four classical methods of DNA extraction were tested, including three cetyltrimethylammonium bromide (CTAB)-based and one sodium dodecyl sulfate (SDS)-based methods. Three drying methods for leaves samples were also evaluated including drying at room temperature (RT), in an oven at $40^{\circ} \mathrm{C}$ (S40), and in a microwave oven (FMO). The DNA solutions obtained from different types of leaves samples using the five protocols were assessed in terms of cost, execution time, and quality and yield of extracted DNA. The commercial kit did not extract DNA with sufficient quantity or quality for successful PCR reactions. Among the classic methods, only the protocols of Dellaporta and of Khanuja yielded DNA extractions for all three types of foliar samples that resulted in successful PCR reactions and subsequent enzyme restriction assays. Based on the evaluated variables, the most appropriate DNA extraction method for Nectandra megapotamica (Spreng.) Mez. was that of Dellaporta, regardless of the method used to dry the samples. The selected method has a relatively low cost and total execution time. Moreover, the quality and quantity of DNA extracted using this method was sufficient for DNA sequence amplification using PCR reactions and to get restriction fragments.
\end{abstract}

Key words: CTAB. SDS. Cost. Quality. Yield.

\section{Resumo}

O objetivo do estudo foi estabelecer um protocolo de isolamento de DNA de Nectandra megapotamica (Spreng.) Mez., capaz de obter amostras de alto rendimento e qualidade para emprego em análises genômicas. Foram testados um kit comercial e quatro métodos clássicos de extração de DNA, incluindo três métodos baseados em brometo de cetiltrimetilamônio (CTAB) e um baseado em dodecil sulfato de sódio (SDS). Três métodos de secagem de amostras de folhas foram também avaliados, incluindo

1 Discente do Curso de Doutorado do Programa de Pós-Graduação em Engenharia Florestal, Universidade Federal de Santa Maria, UFSM, Santa Maria, RS, Brasil. Bolsista CNPq. E-mail: leonardosev@gmail.com

2 Prof $^{\mathrm{a}}$ Dra $^{\mathrm{a}}$, Departamento de Fitotecnia, UFSM, Santa Maria, RS, Brasil. Bolsista PQ/CNPq. E-mail: liarsr@ufsm.br

3 Prof. Dr., Departamento de Ciências Rurais, Universidade Federal do Pampa, UNIPAMPA, São Gabriel, RS, Brasil. E-mail: valdirstefenon@unipampa.edu.br

4 Prof ${ }^{\mathrm{a}}$ Dr$^{\mathrm{a}}$, Departamento de Farmácia Industrial, UFSM, Santa Maria, RS, Brasil. Bolsista PQ/CNPq. E-mail: berta.heinzmann@ gmail.com

5 Discente do Curso de Graduação em Tecnologia de Alimentos, UFSM, Santa Maria, RS, Brasil. E-mail: adrieltca@gmail.com

* Author for correspondence 
a secagem à temperatura ambiente (RT), em estufa a $40^{\circ} \mathrm{C}(\mathrm{S} 40)$, e em forno microondas (FMO). As soluções de DNA obtidas a partir de diferentes tipos de amostras foliares utilizando os cinco protocolos foram avaliadas em termos de custo, tempo de execução e qualidade e rendimento de DNA extraído. $\mathrm{O}$ kit comercial não extraiu DNA com quantidade ou qualidade suficiente para o sucesso das reações de PCR. Entre os métodos clássicos, apenas os protocolos Dellaporta e Khanuja proporcionaram extração de DNA para os três tipos de amostras foliares, que resultaram em reações de PCR e ensaios com enzimas de restrição bem sucedidos. Com base nas variáveis avaliadas, o método de extração de DNA mais apropriado para Nectandra megapotamica (Spreng.) Mez. foi o Dellaporta, independentemente do método utilizado para secar as amostras. O método selecionado apresenta custo e tempo de execução total relativamente baixos. Além disso, a qualidade e quantidade do DNA extraído utilizando o método foram suficientes para amplificação de fragmentos de DNA por meio de reações de PCR e para obter fragmentos de restrição.

Palavras-chave: CTAB. SDS. Custo. Qualidade. Rendimento.

\section{Introduction}

Nectandra megapotamica (Spreng.) Mez. (Lauraceae), popularly known in Brazil as "canelapreta" is a tree species native to the Atlantic Forest, which shows some medicinal properties, such as anti-rheumatic and analgesic (SANTOSFILHO; GILBERT, 1975), anesthetic (TONDOLO et al., 2013), sedative (ALVES et al., 2008), antiinflammatory (SILVA et al., 2004), anti-oxidizing, anti-microbial (GARCEZ et al., 2009), and antitumoral (SILVA et al., 2004). Forest species, particularly those that show medicinal properties, usually have high levels of secondary metabolites that complicate the isolation of pure DNA. High quantities of polysaccharides, polyphenols, and secondary metabolites, such as alkaloids, flavonoids, and tannins, interfere with the isolation of genomic DNA (MISHRA et al., 2008) mainly by co-precipitating irreversibly with nucleic acids (DABO et al., 1993; VARMA et al., 2007). Therefore, the attributes that make it interesting from a pharmacological point of view are simultaneously those that make difficult genetic studies, as well as genomic and transcriptomic assays. Such studies are important towards assist, allow, increase and / or accelerate in vitro biosynthesis of substances that are relevant for human and animal health and plant protection, especially with respect to the organic system.

Contamination with polysaccharides gives isolated DNA a highly viscous consistency, which makes it difficult to pipette and precludes its use in enzymatic reactions (DO; ADAMS, 1991). Extraction with phenol is highly efficient for removing polysaccharides (GEHRIG et al., 2000; PADMALATHA; PRASAD, 2006; TEL-ZUR et al., 1999); however, due to its high toxicity and the restrictions regarding its disposal, its usage has been limited. A quick, efficient, and low-cost alternative to remove polysaccharide contamination is the application of high concentrations of sodium chloride $(\mathrm{NaCl})$ (FANG et al., 1992; LODHI et al., 1994). Another drawback is the presence of phenolic compounds which results in an oxidized, browned DNA (GUILLEMAUT; MARÉCHALDROUARD, 1992; KATTERMAN; SHATTUCK, 1983). To remove these compounds, present in high quantities in mature and inadequately stored leaves, polyvinylpyrrolidone has been used by several authors (CRUZ et al., 1997; KIM et al., 1997; POREBSKI et al., 1997).

For the application of diverse genomic techniques, sufficient quantities of high quality genomic DNA is necessary (SAHU et al., 2012). The DNA isolation protocol must comply with various requirements such as breaking cellular walls and membranes, inhibiting the action of deoxyribonucleases (DNAses), separating nucleic acids from proteins and polysaccharides, and protecting nucleic acids from action of phenolic compounds, thus preventing its oxidation.

Similarly, the methodologies used to collect, process and store plant tissue samples for DNA 
isolation are directly related to the quality of the isolated nucleic acid. In the case of forest tree species, in particular, which are under development, in most cases, in places distant from research laboratories, coupled with difficulties in collecting due to the large size and small number of individuals available, the sample storage during transport to the laboratory and after your arrival, it is essential to keep them viable for long periods of time (BHATTACHARJEE et al., 2009). The most common method for preserving foliar samples is to store them in plastic bags with hermetic seals containing silica gel (CHASE; HILLS, 1991). This procedure is efficient because it quickly dehydrates plant material, thus preventing DNA degradation (ŠTORCHOVÁ et al., 2000). It has numerous advantages, such as low cost, simplicity, and the possibility of reusing and preserving the material for long periods. Furthermore, in its dehydrated state, DNA is less susceptible to chemical or enzymatic degradation (MURRAY; THOMPSON, 1980). An alternative to silica gel is the dehydration via a forced-air circulation oven. While silica gel is used at room temperature and absorbs humidity, dehydration occurs at an elevated temperature with circulation and renovation of the air. For both methods, the drying procedure aims to reduce material deterioration by water content reduction, preventing enzyme and microorganism action and enabling long-term sample preservation (SILVA; CASALI, 2000).

Aiming to optimize a protocol for DNA isolation which overcomes such difficulties, this study evaluated three drying methods for foliar samples and five methodologies for genomic DNA isolation of $N$. megapotamica (Spreng.) Mez., comparing purity, concentration, execution time and cost per sample.

\section{Materials and Methods}

\section{Plant material and drying methods}

Leaves samples from 20 individuals of $N$. megapotamica (Spreng.) Mez. were collected in bulk, homogenized, and divided into three equal subsamples. The first subsample was dried at room temperature (RT), the second was dried in a forcedair circulation oven with a constant temperature of $40^{\circ} \mathrm{C}$ for $24 \mathrm{~h}(\mathrm{~S} 40)$, and the third was dried in a microwave oven for 2 min (FMO). After drying, all subsamples were stored in individual paper bags and kept at RT. For each drying method eight replications were performed.

\section{DNA isolation protocols}

After drying, $150 \mathrm{mg}$ of foliar sample from each drying treatment were macerated with liquid nitrogen and immediately inserted into $2.0 \mathrm{~mL}$ microtubes. Five genomic DNA isolation methods were tested: the QIAGEN DNeasy Plant Mini ${ }^{\mathrm{TM}}$ Kit (Q) following the manufacturer's instructions; three methods using the cationic detergent cetyltrimethylammonium bromide (CTAB): Ferreira and Grattapaglia (1996) (F), Mazza and Bittencourt (2000) (M), and Khanuja et al. (1999) (K); and one method using the detergent sodium dodecyl sulfate (SDS): Dellaporta et al. (1983) (D). For each DNA isolation method eight replications were performed. Table 1 presents the main characteristics of each protocol.

\section{Cost and time estimation}

The cost and execution time of the DNA isolation procedures were assessed following the method proposed by Chen et al. (2010). The cost of each method was estimated by summing the costs of the chemical products, enzymes, and disposable products (microtubes and micro-pipette tips) used in a single extraction of $150 \mathrm{mg}$ of plant tissue. The minimum time required to complete the DNA isolation was estimated for each method, including incubation, centrifugation and drying. The preliminary stages of weighting and maceration of plant tissue in liquid nitrogen were not considered. 
Table 1. Comparative list of steps and chemicals used in DNA isolation methods Nectandra megapotamica (Spreng.) Mez.

\begin{tabular}{|c|c|c|c|c|}
\hline \multirow[b]{2}{*}{ Chemicals } & \multicolumn{4}{|c|}{ Methods } \\
\hline & Dellaporta (D) & $\begin{array}{c}\text { Ferreira and } \\
\text { Grattapaglia (F) } \\
\end{array}$ & Khanuja (K) & $\begin{array}{c}\text { Mazza and } \\
\text { Bittencourt (M) }\end{array}$ \\
\hline Lysis buffer & $\begin{array}{c}\text { SDS 20\%; Tris } \\
\text { HCl 100mM pH } \\
8,0 ; \mathrm{NaCl} 500 \mathrm{mM} \text {; } \\
\text { EDTA 50mM, } \\
\beta \text {-Mercaptoethanol } \\
0,2 \%\end{array}$ & $\begin{array}{c}\text { CTAB 2\%; Tris } \\
\text { HCl } 100 \mathrm{mM} \mathrm{pH} \\
\text { 8,0; NaCl 1,4M; } \\
\text { EDTA 20 mM; } \\
\beta \text {-Mercaptoethanol } \\
0,2 \%\end{array}$ & $\begin{array}{c}\text { CTAB 2,5\%; Tris } \\
\text { HCl } 100 \mathrm{mM} \mathrm{pH} \\
\text { 8,0; NaCl 1,5M; } \\
\text { EDTA } 25 \mathrm{mM} ; \\
\beta \text {-Mercaptoethanol } \\
\text { 0,2\%; PVP } 1 \%\end{array}$ & $\begin{array}{c}\text { CTAB 2\%; Tris } \\
\text { HCl } 100 \mathrm{mM} \mathrm{pH} \\
8,0 ; \text { EDTA } 20 \mathrm{mM} ; \\
\beta \text {-Mercaptoethanol } \\
\text { 0,1\%; PVP 1\%; } \\
\text { Proteinase K 0,01\% } \\
\text { (20mg/mL) }\end{array}$ \\
\hline Potassium Acetate & $5 \mathrm{M}$ & --- & --- & --- \\
\hline Sodium Acetate & $3 \mathrm{M}$ & --- & --- & --- \\
\hline Iso-propanol & Absolute & --- & --- & --- \\
\hline $\begin{array}{l}\text { Chloroform Isoamil } \\
\text { Alcohol (CIA) }\end{array}$ & --- & $24: 1(\mathrm{v} / \mathrm{v})$ & $24: 1(\mathrm{v} / \mathrm{v})$ & $24: 1(\mathrm{v} / \mathrm{v})$ \\
\hline RNase & --- & --- & --- & $3 \mu \mathrm{l}(10 \mathrm{mg} / \mathrm{mL})$ \\
\hline Sodium Chloride $(\mathrm{NaCl})$ & --- & --- & $5 \mathrm{M}$ & --- \\
\hline Iso-propanol & --- & --- & Absolute & --- \\
\hline Ethanol & --- & --- & $80 \%$ & --- \\
\hline High Salt TE & --- & --- & $\begin{array}{c}\mathrm{NaCl} 1 \mathrm{M} \text {; Tris- } \mathrm{HCl} \\
\text { 10mM; EDTA } 1 \\
\text { mM }\end{array}$ & --- \\
\hline TE buffer & $\begin{array}{c}\text { Tris- } \mathrm{HCl} 50 \mathrm{mM} \\
\mathrm{pH} 8,0 \text { and EDTA } \\
10 \mathrm{mM}\end{array}$ & --- & --- & --- \\
\hline RNase & --- & --- & $5 \mu \mathrm{l}(10 \mathrm{mg} / \mathrm{mL})$ & --- \\
\hline CIA & $24: 1(\mathrm{v} / \mathrm{v})$ & --- & $24: 1(\mathrm{v} / \mathrm{v})$ & $24: 1(\mathrm{v} / \mathrm{v})$ \\
\hline Acetate sodium & $3 \mathrm{M}$ & --- & --- & --- \\
\hline Iso-propanol & --- & Absolute & --- & Absolute \\
\hline Ethanol & $80 \%$ & $70 \%$ and $99.99 \%$ & $99.99 \%$ and $80 \%$ & $70 \%$ and $95 \%$ \\
\hline TE & $\begin{array}{c}\text { Tris- } \mathrm{HCl} 10 \mathrm{mM} \\
\mathrm{pH} 8,0 \text { and EDTA } \\
1 \mathrm{mM}\end{array}$ & $\begin{array}{l}\text { Tris-HCl } 1 \mathrm{M} \mathrm{pH} \mathrm{8,0} \\
\text { and EDTA } 500 \mathrm{mM}\end{array}$ & Water & $\begin{array}{l}\text { Tris- } \mathrm{HCl} 10 \mathrm{mM} \mathrm{pH} \\
8,0 \text { and EDTA } 1 \mathrm{mM}\end{array}$ \\
\hline RNase & --- & $3 \mu \mathrm{l}(10 \mathrm{mg} / \mathrm{mL})$ & --- & --- \\
\hline
\end{tabular}

\section{DNA yield and quality analysis}

The quality and yield of the isolated DNA solutions were assessed with an UV-Vis NanoDrop ND-1000 spectrophotometer. For quality analysis, the ratio of absorbance at $\mathrm{OD}_{260 / 280}$ (optical density gradient) was considered.

\section{DNA restriction and amplification}

The digestion reactions were performed in an Eppendorf MasterCycler thermocycler ${ }^{\mathrm{TM}}$, with a final volume of $25 \mu \mathrm{L}$, containing $50 \mathrm{ng}$ of DNA, $10 \mathrm{U}$ of MseI enzyme and $20 \mathrm{U}$ of Pst enzyme, incubated at $37^{\circ} \mathrm{C}$ for $24 \mathrm{~h}$. For the PCR amplification reactions, six RAPD primers were used. The primers (Table 2) were selected according to the results obtained by Hanai et al. (2010) using Ocotea catharinensis (Lauraceae). The amplification reactions were performed in an AmpliTherm TX96 Plus $^{\mathrm{TM}}$ thermocycler. Each amplification reaction $(25 \mu \mathrm{L})$ contained $10 \mathrm{mM}$ TRIS- $\mathrm{HCl}(\mathrm{pH} 8.3), 50$ $\mathrm{mM} \mathrm{KCl}, 3 \mathrm{mM}$ of $\mathrm{MgCl}_{z}, 0.2 \mathrm{mM}$ of dNTPs, 0.25 
$\mu \mathrm{M}$ of RAPD primers (Sigma-Aldrich, St. Louis, MO, USA), 20 ng of DNA, $1.5 \mathrm{U}_{\mu} \mathrm{L}^{-1}$ of Taq DNA Polymerase (Thermo Fisher Scientific, Waltham, MA, USA) and ultra-pure water. The thermal profile consisted of an initial denaturing stage at $94^{\circ} \mathrm{C}$ for $5 \mathrm{~min}$, followed by 45 cycles of denaturing at $94^{\circ} \mathrm{C}$ for $1 \mathrm{~min}$, annealing at $35^{\circ} \mathrm{C}$ for $1 \mathrm{~min}$ and elongation at $72^{\circ} \mathrm{C}$ for $2 \mathrm{~min}$, with a final extension of $72^{\circ} \mathrm{C}$ for $6 \mathrm{~min}$. The amplification and digestion products were resolved through electrophoresis in agarose gel $1.5 \%(\mathrm{p} / \mathrm{v})$.

Table 2. List of RAPD primers used in PCR reactions with DNA samples from Nectandra megapotamica (Spreng.) Mez.

\begin{tabular}{cc}
\hline Primer & Sequence \\
\hline OPA $-02(\mathrm{~A})$ & $5^{\prime}$-TGCCGAGCTG-3' \\
OPA $-04(\mathrm{~B})$ & $5^{\prime}$-AATCGGGCTG-3' \\
OPA $-07(\mathrm{C})$ & $5^{\prime}$-GAAACGGGTG-3' \\
OPA $-10(\mathrm{D})$ & $5^{\prime}$-GTGATCGCAG-3' \\
OPA $-11(\mathrm{E})$ & $5^{\prime}$-CAATCGCCGT-3' \\
OPA $-12(\mathrm{~F})$ & $5^{\prime}$-TCGGCGATAG-3' \\
\hline
\end{tabular}

\section{Results and Discussion}

The concentration and quality of isolated DNA for each of the five methods are summarized in Table 3. For all leaves samples, the quantity of DNA isolated with the commercial kit was significantly lower than the quantities isolated using the classic methods. Independent of the drying method, the highest concentration was obtained with the $\mathrm{M}$ procedure, which might be explained by the presence of Proteinase K. This enzyme inhibits the action of the nucleases that are released during cellular lysis, thus preventing degradation of DNA (ALEKSANDRUSHKINA; VANYUSHIN, 2009; $\mathrm{OH}$ et al., 2013). Drying RT resulted in a higher DNA concentration than that observed in the other two methods.

Regarding DNA purity, the $\mathrm{OD}_{260 / 280}$ for the procedures $\mathrm{D}, \mathrm{F}$ and $\mathrm{K}$ were higher than 2.0, indicating presence of RNA residues. Usually, RNase treatment is employed at various stages of isolation to remove these residues. Despite the use of a final stage of RNase treatment, all isolation protocols tested show RNA residues, with special emphasis on $\mathrm{F}$ and $\mathrm{K}$, despite the treatment with RNase. The procedures $\mathrm{F}$ and $\mathrm{K}$ revealed the highest values for the ratio $\mathrm{OD}_{260 / 280}$ (Table 1). In F
$3.0 \mu 1(10 \mathrm{mg} / \mathrm{ml})$ of RNase is added at the end of the process unlike that occurs in method $\mathrm{K}$, where $5.0 \mu 1(10 \mathrm{mg} / \mathrm{ml})$ ribonuclease is inserted between two washes with CIA. In M, $3.0 \mu 1(10 \mathrm{mg} / \mathrm{ml})$ of RNase is added between two washes with CIA, which seems to result in greater efficiency. The higher quantity of residues in the DNA solution is also supported by the $\mathrm{OD}_{260 / 280}$ and the digestion with restriction enzymes.

Although the DNA isolated using the methods $\mathrm{D}$ and $\mathrm{K}$ showed evidence of RNA contamination, amplification of DNA sequences was successful (Figure 1) for the three types of foliar samples. Using the DNA obtained with the protocol F, the amplification only occurred in RT samples, consistent with the $M$ procedure. Using the DNA obtained with the method Q, no amplification occurred in all foliar samples.

Across the drying methods tested RT showed the best results in all protocols. Taylor and Swann (1994) report that samples dried at room temperature or up to $42^{\circ} \mathrm{C}$, resulting in a useful amount of high molecular weight DNA and good quality, while the samples dried in a microwave oven show poor quality DNA. However, in this study the FMO samples showed better results than $\mathrm{S} 40$ in all methods, except in $\mathrm{K}$. 
Table 3. Averaged values of yield and quality DNA isolated from leaf samples from Nectandra megapotamica (Spreng.) Mez. by different methods (eight replicates were performed for each method of isolation).

\begin{tabular}{lcccc}
\hline \multirow{2}{*}{ Isolation method } & Sample & DNA yield (mean \pm SE) (ng) & \multicolumn{2}{c}{ OD $_{\text {260/280 }}$} \\
& Mean \pm SE & Variation \\
\hline \multirow{2}{*}{ Kit QIAGEN DNeasy Plant } & RT & $14.27 \pm 1.64$ & $1.61 \pm 0.04$ & $1.56-1.67$ \\
Mini $^{\text {TM }}$ & S40 & $16.36 \pm 2.50$ & $1.54 \pm 0.10$ & $1.42-1.70$ \\
& FMO & $23.77 \pm 9.65$ & $1.71 \pm 0.05$ & $1.63-1.78$ \\
Dellaporta et al. (1983) & RT & $362.04 \pm 51.33$ & $2.05 \pm 0.01$ & $2.03-2.07$ \\
& S40 & $174.4 \pm 114.50$ & $2.17 \pm 0.52$ & $1.76-3.45$ \\
& FMO & $157.48 \pm 77.39$ & $2.14 \pm 0.12$ & $2.06-2.44$ \\
Ferreira and Grattapaglia (1996) & RT & $502.26 \pm 101.79$ & $2.21 \pm 0.09$ & $2.09-2.38$ \\
& S40 & $351.55 \pm 57.98$ & $2.40 \pm 0.18$ & $2.21-2.77$ \\
& FMO & $408.96 \pm 90.92$ & $2.29 \pm 0.26$ & $1.97-2.77$ \\
Khanuja et al. (1999) & RT & $243.06 \pm 72.55$ & $2.25 \pm 0.08$ & $2.19-2.42$ \\
& S40 & $76.27 \pm 10.55$ & $2.40 \pm 0.12$ & $2.23-2.60$ \\
& FMO & $81.32 \pm 24.40$ & $2.57 \pm 0.15$ & $2.28-2.77$ \\
Mazza and Bittencourt (2000) & RT & $849.58 \pm 214.77$ & $1.80 \pm 0.05$ & $1.73-1.90$ \\
& S40 & $547.74 \pm 43.67$ & $1.55 \pm 0.02$ & $1.51-1.58$ \\
& FMO & $676.24 \pm 116.12$ & $1.70 \pm 0.05$ & $1.61-1.78$ \\
\hline
\end{tabular}

$\mathrm{RT}=$ drying at room temperature; $\mathrm{S} 40=$ drying in a forced-air circulation oven with a constant temperature of $40^{\circ} \mathrm{C}$; $\mathrm{FMO}=\mathrm{drying}$ in a microwave; $\mathrm{OD}=$ optical density gradient.

Digestion of DNA by restriction enzymes for each of the protocols and foliar samples is shown in Figure 2. Regardless of the drying method occurred digestion, except in method $\mathrm{F}$ and $\mathrm{Q}$.

The DNA isolated from each foliar sample using the $\mathrm{F}$ protocol had a viscous appearance and light brown color, characteristic of contamination by polysaccharides and phenolic compounds, respectively (SANGWAN et al., 1998; SHIODA; MARAKAMI-MUOFUSHI, 1987; TEL-ZUR et al., 1999). These properties inhibited the digestion of these DNA solutions. The samples were trapped in the gel wells during separation of the molecules through electrophoresis, confirming the presence of polysaccharide contamination (SHARMA; PUROHIT, 2012).

The presence of RNA did not prevent digestion with restriction enzymes and PCR reactions. Some authors suggest that RNA contamination does not pose a problem for the subsequent application of the isolated DNA in PCR reactions, since it is degraded at high temperatures and in the presence of magnesium ions (MURRAY; THOMPSON, 1980; HOUSELEY; TOLLERVEY, 2009; TAN et al., 2013).

Unlike RNA contamination, the presence of polysaccharides and phenolic compounds interferes in the efficiency of PCR reactions and enzymatic digestion, because it inhibits the action of Taq DNA polymerase and restriction enzymes (JAPELAGHI et al., 2011; IANDOLINO et al., 2004; MOSER et al., 2004; PANDEY et al., 1996; FANG et al., 1992). Contamination by phenolic compounds is commonly observed in DNA isolation protocols (VARMA et al., 2007), since these compounds are released during cellular lysis and suffer from the action of the polyphenol oxidase enzyme, which causes oxidation of phenolic compounds when in contact with oxygen (CHOUDHARY et al., 2008; LOMMIS, 1974; MOHAMMADI et al., 2009). 
Figure 1. PCR reaction products for samples of DNA from Nectandra megapotamica (Spreng.) Mez. using RAPD primers. The first and last lines correspond to the $1 \mathrm{~kb}$ molecular weight marker (MP) (Ludwig, Porto Alegre, RS, Brazil). The first letter of the other lines indicates the protocol used: Ferreira and Grattapaglia (1996) (F), Mazza and Bittencourt (2000) (M), Dellaporta et al. (1983) (D), Khanuja et al. (1999) (K), and QIAGEN DNeasy Plant Mini $\mathrm{Kit}^{\mathrm{TM}}(\mathrm{Q})$. The second letter indicates the primer: OPA 02 (A), OPA 04 (B), OPA 07 (C), OPA 10 (D), OPA 11 (E), and OPA 12 (F). Two negative controls were used with primers OPA $02(\mathrm{CNA})$ and OPA 11 (CNF). RT = Samples dried at room temperature. $\mathrm{S} 40=$ samples dried in a forced-air circulation oven at $40^{\circ} \mathrm{C}$. $\mathrm{FMO}=$ samples dried in a microwave oven.

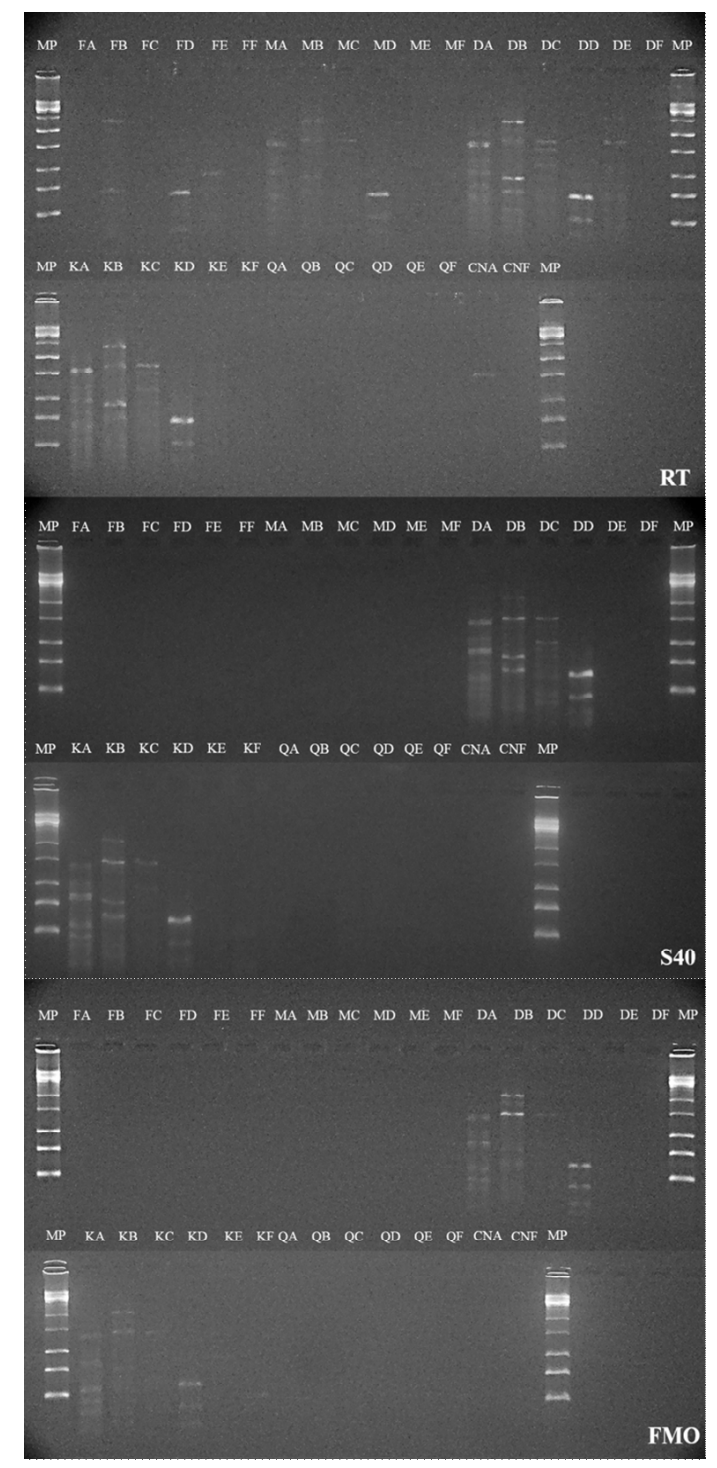

The estimated cost in dollars (USD) and the execution times for each DNA isolation method for $150 \mathrm{mg}$ dried foliar tissue samples are shown in Table 4. The results show that the Q procedure is the fastest isolation method and has the highest cost. Commercial kits for DNA isolation, in general, are faster and more expensive (with respect to the cost of reagents) than traditional procedures (VARMA et al., 2007). However, the results obtained using kits may be inefficient in terms of quality and quantity of isolated DNA, especially when the species under study contains high levels of polyphenols and polysaccharides (MICHIELS et al., 2003; SANGWAN et al., 1998). Additionally, considering 
the high cost per sample of the commercial kits, their use is not feasible in studies involving large quantities of samples (RIBEIRO; LOVATO, 2007). The four traditional DNA isolation methods showed longer execution times than the commercial kit; however, they had a significantly lower cost. Due to the large diversity of polyphenols, polysaccharides, and secondary metabolites in plant species, optimized species-specific DNA isolation procedures are often required.

Figure 2. Digestion of DNA using five isolation methods for Nectandra megapotamica (Spreng.) Mez. with restriction enzymes MseI and PstI. The first and last lines correspond to the $1 \mathrm{~kb}$ molecular weight marker (MP) (Ludwig, Porto Alegre, RS, Brazil). The first letter of the other lines indicates the protocol used: Ferreira and Grattapaglia (1996) (F), Mazza and Bittencourt (2000) (M), Dellaporta et al. (1983) (D), Khanuja et al. (1999) (K), and QIAGEN DNeasy Plant Mini Kit ${ }^{\mathrm{TM}}(\mathrm{Q})$. The number after the first letter in each line indicates the repetition. The method for drying foliar samples is represented by RT (dried at room temperature), S40 (dried in a forced-air circulation oven at $40^{\circ} \mathrm{C}$ ) and FMO (dried in microwave oven).

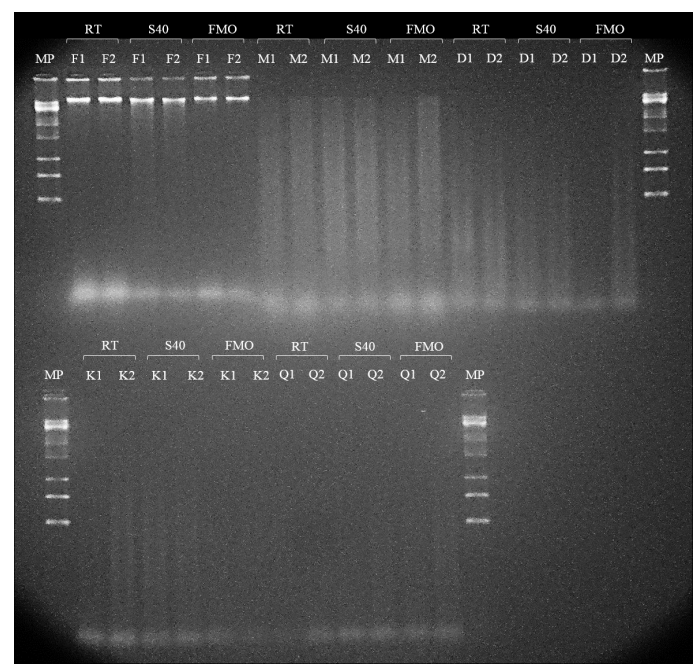

Table 4. Estimated execution time and cost for each DNA sample from Nectandra megapotamica (Spreng.) Mez. by five extraction methods.

\begin{tabular}{lcc}
\hline Isolation method & Execution time (h:min) & Cost (USD) \\
\hline Kit QIAGEN DNeasy Plant Mini ${ }^{\mathrm{TM}}$ (Q) & $01: 00$ & 6.78 \\
Dellaporta et al. (1983) (D) & $04: 42$ & 0.12 \\
Ferreira and Grattapaglia (1996) (F) & $04: 10$ & 0.15 \\
Khanuja et al. (1999) (K) & $04: 10$ & 0.19 \\
Mazza and Bittencourt (2000) (M) & $05: 10$ & 0.12 \\
\hline
\end{tabular}

\section{Conclusions}

The results of this study indicate that the most efficient DNA isolation protocol for foliar samples of $N$. megapotamica is the method proposed by Dellaporta et al. (1983). It enabled isolation of DNA in adequate quantities and quality for subsequent applications, such as PCR reactions and digestion by restriction endonucleases. This procedure is less expensive and more versatile than the others, allowing for the use of isolated DNA solutions from foliar samples dried at RT, in a forced-air circulation oven, or in a microwave oven to obtain PCR products and restriction fragments. 


\section{Acknowledgments}

The authors would like to thank CNPq (Conselho Nacional de Desenvolvimento Científico e Tecnológico).

\section{References}

ALEKSANDRUSHKINA, N. I.; VANYUSHIN, B. F. Endonucleases and their involvement in plant apoptosis. Russian Journal Plant Physiology, Moscow, v. 56, n. 3, p. 291-305, 2009.

ALVES, E. O.; MOTA, J. H.; SOARES, T. S.; VIEIRA, M. C.; SILVA, C. B. Levantamento etnobotânico e caracterização de plantas medicinais em fragmentos florestais de Dourados-MS. Ciência e Agrotecnologia, Lavras, v. 32, n. 2, p. 651-658, 2008.

BHATTACHARJEE, R.; FERGUSON, M.; GEDIL, M.; DUMET, D.; INGELBRECHT, I. Field collection, preservation and large scale DNA extraction procedures for cassava (Manihot esculenta Crantz.). African Journal of Biotechnology, Nairobi, v. 8, n. 15, p. 3424-3430, 2009.

CHASE, M. W.; HILLS, H. H. Silica gel: an ideal material for field preservation of leaf samples for DNA studies. Taxon, Bratislava, v. 40, n. 2, p. 215-220, 1991.

CHEN, H.; RANGASAMY, M.; TAN, S. Y.; WANG, H.; SIEGFRIED, B. D. Evaluation of five methods for total DNA extraction from Western Corn Rootworm Beetles. Plos One, Cambridge, v. 5, n. 8, p. 1-6, 2010.

CHOUDHARY, K.; MATHUR, N.; CHOUDHARY, O. P.; PILLAI, U. Protocol for isolation of genomic DNA from dry and fresh leaves of Vigna species suitable for RAPD and restriction digestion. Advances in Biological Research, Rennes, v. 2, n. 5-6, p. 83-89, 2008.

CRUZ, M.; RAMIREZ, F.; HERNANDEZ, H. DNA isolation and amplification from Cacti. Plant Molecular Biology Reporter, New York, v. 15, n. 4, p. 319-325, 1997.

DABO, S. M.; MITCHELL, E. D.; MELCHER, U. A method for the isolation of nuclear DNA from cotton (Gossypium) leaves. Analytical Biochemistry, New York, v. 210, n. 1, p. 34-38, 1993.

DELLAPORTA, S. L.; WOOD, J.; HICKS, J. B. A plant DNA Minipreparation: version II. Plant Molecular Biology Reporter, New York, v. 1, n. 4, p. 19-21, 1983.

DO, N.; ADAMS, R. P. A simples technique for removing plant polysaccharide contaminants from DNA. Biotechniques, London, v. 10, n. 2, p. 162-166, 1991.
FANG, G.; HAMMAR, S.; GRUMET, R. A quick and inexpensive method for removing polysaccharides from plant genomic DNA. Biotechniques, London, v. 13, n. 1, p. 52-55, 1992.

FERREIRA, M. E.; GRATTAPAGLIA, D. Introdução ao uso de marcadores moleculares em análise genética. Brasília: Embrapa-CENARGEM, 1996. 220 p.

GARCEZ, F. R.; GARCEZ, W. S.; HAMERSKI, L.; MIGUITA, C. H. Phenylpropanoids and other bioactive constituintes from Nectandra megapotamica. Química Nova, São Paulo, v. 32, n. 2, p. 407-411, 2009.

GEHRIG, H. H.; WINTER, K.; CUSHMAN, J.; BORLAND, A.; TAYBI, T. An improved RNA isolation method for succulent plant species rich in polyphenols and polysaccharides. Plant Molecular Biology Reporter, New York, v. 18, n. 4, p. 369-376, 2000.

GUILLEMAUT, P.; MARÉCHAL-DROUARD, L. Isolation of plant DNA: a fast, inexpensive, and reliable method. Plant Molecular Biology Reporter, New York, v. 10, n. 1, p. 60-65, 1992.

HANAI, L. R.; FLOH, E. I. S.; FUNGARO, M. H. P.; SANTA-CATARINA, C.; PAULA, F. M.; VIANA, A. M.; VIEIRA, M. L. C. Methylation patterns revealed by MSAP profiling in genetically stable somatic embryogenic cultures of Ocotea catharinensis (Lauraceae). In Vitro Cellular \& Developmental Biology - Plant, London, v. 46, n. 4, p. 368-377, 2010.

HOUSELEY, J.; TOLLERVEY, D. The many pathways of RNA degradation. Cell, Cambridge, v. 136, n. 4, p. 763-776, 2009.

IANDOLINO, A. B.; SILVA, F. G.; LIM, H.; CHOI, H.; WILLIAMS, L. E.; COOK, D. R. High-quality RNA, cDNA, and derived EST libraries from grapevine (Vitis vinifera L.). Plant Molecular Biology Reporter, New York, v. 22, n. 3, p. 269-278, 2004.

JAPELAGHI, R. H.; HADDAD, R.; GAROOSI, G-A. Rapid and eficiente isolation of high quality nucleic acids from plant tissues rich in polyphenols and polysaccharides. Molecular Biotechnology, v. 49, n. 2, p. 129-137, 2011.

KATTERMAN, F. R.; SHATTUCK, V. I. An effective method of DNA isolation from the mature leaves of Gossypium species that contain large amounts of phenolic terpenoids and tannins. Preparative Biochemistry \& Biotechnology, New York, v. 13, n. 4, p. 347-359, 1983.

KHANUJA, S. P. S.; SHASANY, A. K.; DAROKAR, M. P.; KUMAR, S. Rapid isolation of DNA from dry and fresh samples of plants producing large amounts of secondary metabolites and essential oils. Plant Molecular Biology Reporter, New York, v. 17, n. 1, p. 1-7, 1999. 
KIM, C. S.; LEE, C. H.; SHIN, J. S.; CHUNG, Y. S.; HYUNG, N. I. A simple and rapid method for isolation of high quality genomic DNA from fruit trees and conifers using PVP. Nucleic Acids Research, Oxford, v. 25, n. 5, p. 1085-1086, 1997.

LODHI, M. A.; YE, G.; WEEDEN, N. F.; REISCH, B. I. A simple and efficient method for DNA extractions from grapevine cultivars and Vitis species. Plant Molecular Biology Reporter, New York, v. 12, n. 1, p. 6-13, 1994.

LOMMIS, M. D. Overcoming problems of phenolic and quinones in the isolation of plant enzymes and organelles. Methods in Enzymology - Biomembranes Part A, Cambridge, v. 31, p. 528-544, 1974.

MAZZA, M. C. M.; BITTENCOURT, J. V. M. Extração de DNA de tecido vegetal de Araucaria angustifolia (Araucariaceae). Boletim de Pesquisa Florestal, Colombo, n. 41, p. 12-17, 2000.

MICHIELS, A.; VAN DEN ENDE, W.; TUCKER, M.; RIET, L. V.; LAERE, A. V. Extraction of high-quality genomic DNA from latex-containing plants. Analytical Biochemistry, New York, v. 315, n. 1, p. 85-89, 2003.

MISHRA, K. M.; RANI, N. S.; RAM, A. S.; SREENATH, H. L. A simple method of DNA extraction from coffee seeds suitable for PCR analysis. African Journal of Biotechnology, Nairobi, v. 7, n. 4, p. 409-413, 2008.

MOHAMMADI, A.; MOGHADDAM, A. B.; DINARVAND, R.; REZAI-ZARCHI, S. Direct electron transfer of polyphenol oxidase on carbon nanotube surfaces: Aplication in Biosensing. International Journal of Electrochemical Science, Belgrade, v. 4, n. 7, p. 895905, 2009.

MOSER, C.; GATTO, P.; MOSER, M.; PINDO, M.; VELASCO, R. Isolation of functional RNA from small amounts of different grape and apple tissues. Molecular Biotechnology, Burlington, v. 26, n. 2, p. 95-99, 2004.

MURRAY, M. G.; THOMPSON, W. F. Rapid isolation of high molecular weight plant DNA. Nucleic Acids Research, Oxford, v. 8, n. 19, p. 4321-4325, 1980.

OH, S. Y.; KIM, W. Y.; HWANG, T. S.; HAN, H. S.; LIM, S. D.; KIM, W. S. Development of an ammonium sulfate DNA extraction method for obtaining amplifiable DNA in a small number of cells and its application to clinical specimens. BioMed Research International, New York, v. 2013, p. 1-10, 2013.

PADMALATHA, K.; PRASAD, M. N. V. Optimization of DNA isolation and PCR protocol for RAPD analysis of selected medicinal and aromatic plants of conservation concern from Peninsular India. African Journal of Biotechnology, Nairobi, v. 5, n. 3, p. 230-234, 2006.
PANDEY, R. N.; ADAMS, R. P.; FLOURNOY, L. E. Inhibition of random amplified polymorphic DNAs (RAPDs) by plant polysaccharides. Plant Molecular Biology Reporter, New York, v. 14, n. 1, p. 17-22, 1996.

POREBSKI, S.; BAILEY, L. G.; BAUM, B. R. Modification of a CTAB DNA extraction protocol for plants containing high polysaccharide and polyphenol components. Plant Molecular Biology Reporter, New York, v. 15, n. 1, p. 8-15, 1997.

RIBEIRO, R. A.; LOVATO, M. B. Comparative analysis of different DNA extraction protocols in fresh and herbarium specimens of the genus Dalbergia. Genetics and Molecular Research, Ribeirão Preto, v. 6, n. 1, p. 173-187, 2007.

SAHU, S. K.; THANGARAJ, M.; KATHIRESAN, $\mathrm{K}$. DNA extraction protocols for plants high levels of secondary metabolities and polysaccharides without using liquid nitrogen and phenol. ISRN Molecular Biology, New York, v. 1, p. 1-6, 2012.

SANGWAN, N. S.; SANGWAN, R. S.; KUMAR, S. Isolation of genomic DNA from the antimalarial plant Artemisia annua. Plant Molecular Biology Reporter, New York, v. 16, n. 4, p. 365-365, 1998.

SANTOS-FILHO, D.; GILBERT, B. The alkaloids of Nectandra megapotamica. Phytochemistry, London, v. 14, n. 3, p. 821-822, 1975.

SHARMA, P.; PUROHIT, S. D. An improved method of DNA isolation from polysaccharide rich leaves of Boswellia serrata Roxb. Indian Journal of Biotechnology, Delhi, v. 11, n. 1, p. 67-71, 2012.

SHIODA, M.; MARAKAMI-MUOFUSHI, K. Selective inhibition of DNA polymerase alpha by a polysaccharide purified from smile of Physarum polycephalum. Biochemical and Biophysical Research Communications, Cambridge, v. 146, n. 1, p. 61-66, 1987.

SILVA, A. A.; SILVA, M. L. A. E.; CARVALHO, J. C. T.; BASTOS, J. K. Evaluation of analgesic and anti-inflamatory activies of Nectandra megapotamica (Lauraceae) in mice and rats. Journal of Pharmacy and Pharmacology, London, v. 56, n. 9, p. 1179-1184, 2004.

SILVA, F.; CASALI, V. W. D. Plantas medicinais e aromáticas: pós-colheita e óleos essenciais. Viçosa, MG: Arte Livros, 2000. 135 p.

ŠTORCHOVÁ, H.; HRDLIČKOVÁ, R.; CHRTEK JÚNIOR, J.; TETERA, M.; FITZE, D.; FEHRER, J. An improved method of DNA isolation from plants collected in the field and conserved in saturated $\mathrm{NaCl} / \mathrm{CTAB}$ solution. Taxon, Bratislava, v. 49, n. 1, p. 79-84, 2000. 
TAN, H.; HUANG, H.; TIE, M.; MA, J.; LI, H. Comparative analysis of six DNA extraction methods in Cowpea (Vigna unguiculata L. Wap). Journal of Agricultural Science, Cambridge, v. 5, n. 7, p. 82-90, 2013.

TAYLOR, J. W.; SWANN, E. C. Dried samples: soft tissues, DNA from herbarium specimens. 166-181. In: HERRMANN, B.; HUMMEL, S. (Ed.). Ancient DNA. New York: Springer-Verlag, 1994. p. 166-181.

TEL-ZUR, N.; ABBO, S.; MYSLABODSKI, D.; MIZRAHI, Y. Modified CTAB procedure for DNA isolation from Epiphytic Cacti of the genera Hylocereus and Selenicereus (Cactaceae). Plant Molecular Biology Reporter, New York, v. 17, n. 3, p. 249-254, 1999.
TONDOLO, J. S. M.; AMARAL, L. P.; SIMÕES, L. N.; GARLET, Q. I.; SCHINDLER, B.; OLIVEIRA, T. M.; SILVA, B. F.; GOMES, L. C.; BALDISSEROTTO, B.; MALLMANN, C. A.; HEINZMANN, B. M. Anesthesia and transport of fast snook Centropomus parallelus with the essential oil of Nectandra megapotamica (Spreng.) Mez. Neotropical Ichthyology, Porto Alegre, v. 11, n. 3, p. 667-674, 2013.

VARMA, A.; PADH, H.; SHRIVASTAVA, N. Plant genomic DNA isolation: an art or a science. Biotechnology Journal, Weinheim, v. 2, n. 3, p. 386-392, 2007. 
